\title{
ENTRE POTENCIAIS E BLOQUEIOS COMUNICATIVOS: Habermas e a crítica do Estado democrático de direito
}

\author{
Felipe Gonçalves Silva*
}

\begin{abstract}
Para Habermas, uma compreensão crítica do Estado democrático de direito não se faz meramente com a denúncia de seus inúmeros insucessos. Trata-se de investigá-los como bloqueios a suas potencialidades reais. Nesse sentido, em Direito e Democracia, o autor procura reconstruir as condições procedimentais ante as quais pode se mover um processo de democratização radical, submetendo os elementos fundamentais do Estado democrático de direito a um modelo discursivo de teoria crítica, o qual se volta para o aproveitamento dos potenciais comunicativos liberados na modernidade. Partindo dos vínculos de Direito e Democracia com a teoria crítica da sociedade, o artigo pretende explicitar os traços particulares do modelo crítico ali desenvolvido, bem como salientar algumas de suas limitações características.

PALAVRAS-CHAVE: Habermas, democracia, Estado de Direito, teoria crítica, procedimentalismo.
\end{abstract}

Em Direito e Democracia, Habermas procura submeter os elementos fundamentais do Estado democrático de direito a um exame crítico. Já no prefácio do livro, entretanto, o autor nos adianta que seu trabalho não procura se prender a uma crítica "derrotista", vale dizer, a uma crítica que abandona os "conteúdos radicais do Estado democrático de direito" junto com a denúncia de seus insucessos. "Caso contrário, eu deveria escolher um outro gênero literário - talvez o do diário de um escritor helenista preocupado apenas em documentar para a posteridade as promessas não cumpridas de sua cultura decadente.” (Habermas, [1992, p.13] 1997, v.1, p.14). Trata-se, ao contrário, de reelaborar a compreensão desses conteúdos radicais, de modo a investigar sua inscrição nas sociedades complexas atuais e a natureza de seus inúmeros bloqueios. Partindo dos vínculos de Direito e Democracia com a teoria crítica da sociedade, pretende-

* Doutor em Filosofia pela Universidade Estadual de Campinas. Integra o Núcleo de Pesquisa Direito e Democracia do Centro Brasileiro de Análise e Planejamento (CEBRAP) R. Napoleão de Barros, 1222, Ap. 21. Cep: 04024-003. felipegons@hotmail.com mos explicitar os traços particulares do modelo crítico ali desenvolvido. Iniciamos a exposição indicando que o recurso a critérios normativos histórica e socialmente enraizados não deve ser tomado em si mesmo como um afastamento do campo crítico, mas, ao contrário, como um modo peculiar e já difundido de dar a ele continuidade. Em segundo lugar, procuramos mostrar que a escolha do Estado democrático de direito como objeto de crítica não é arbitrária, mas vincula-se a um diagnóstico mais amplo sobre os meios de integração social modernos, o qual atribui às instituições jurídico-democráticas uma posição central na caracterização das possibilidades e bloqueios ao aproveitamento dos potenciais comunicativos liberados na modernidade. A seguir, passaremos por alguns dos momentos reconstrutivos desenvolvidos ao longo da obra, defendendo, junto com o autor, que eles compóem um percurso teórico destinado à submissão progressiva dos elementos fundamentais do Estado democrático de direito a um modelo discursivo e procedimental de teoria crítica. Ao final, defenderemos o caráter programático e inacabado da 
obra, indicando alguns de seus limites mais característicos.

\section{TEORIA CRÍTICA E NORMATIVIDADE ENRAIZADA}

Na literatura filosófica contemporânea, encontramos um empenho coletivo em entender o significado da expressão "teoria crítica da sociedade" como um campo intelectual amplo e plural, o qual, apesar de se manter ainda ligado à produção dos primeiros membros do Instituto de Pesquisa Social em Frankfurt, não pode ser reduzido a nenhum de seus modelos teóricos específicos. E é digno de nota que tal empenho tenha sido assumido por autores que defendem sua continuidade mesmo depois do enfraquecimento de determinadas construções teóricas e estruturas conceituais a ele vinculadas. Dessa forma, ao invés de uma doutrina bem acabada, a teoria crítica é desenvolvida como uma forma abrangente de reflexão intelectual.

No cerne desse campo teórico compartilhado, encontramos a afirmação de uma crítica social imanente, orientada pelas possibilidades concretas de emancipação contra as formas de dominação vigentes. A teoria crítica, pois, desde seus textos inaugurais, assumiria a "orientação pela emancipação" como sua diretriz própria, com a qual afirmaria sua particularidade tanto em relação às ciências sociais positivistas - que em nome de uma observação neutra e distanciada dos fenômenos sociais, limitam-se a "expressar, cada vez melhor [...] o aspecto do mundo miserável que se apresenta aos olhos do cientista" - quanto em relação ao utopismo das reflexões normativas de cunho idealista, as quais, desprovidas de uma compreensão profunda do presente, buscam a avaliação da realidade social em função não de suas possibilidades reais, mas de ideais exteriores ante os quais o teórico consegue exprimir apenas uma "crença na sua realização” (Horkheimer, 1975, p.147). Assim, por um lado, o tipo de reflexão social conduzido pela teoria crítica não se limita à descrição das rotinas de funcionamento das estruturas e relações sociais observadas, mas visa à sua avaliação em nome dos potenciais de emancipação nelas inscritos. Por outro lado, como escreve Marcos Nobre, a perspectiva da emancipação, que figura aqui como vetor performativo da teoria, não é assumida como um "ideal' meramente imaginado pelo teórico, mas uma possibilidade real, inscrita na própria lógica social do capitalismo", o que obriga a teoria a se pautar em diagnósticos do tempo presente capazes de descortinar tendências do desenvolvimento histórico a serem delineadas como potenciais e bloqueios à emancipação:

Do ponto de vista crítico, portanto, a análise do existente a partir da realização do novo - que se insinua no presente, mas que ainda não é - permite a apresentação do presente histórico sob a perspectiva dos obstáculos à realização de suas potencialidades melhores: apresenta o existente do ponto de vista das oportunidades de emancipação relativamente à dominação vigente (Nobre, 2004, p.22-23).

Entretanto, a orientação pela emancipação, que continua a delinear o campo da teoria crítica, teve de passar ela mesma por reflexões e modificações substanciais depois da recusa de certos pressupostos filosóficos que a possibilitavam em suas elaborações primeiras. Entre as rejeições mais enfaticamente explicitadas, encontramos o ataque à retaguarda de uma filosofia da história de repercussões teleológicas, diante da qual as possibilidades de emancipação em relação à dominação capitalista poderiam ser descritas na forma de tendências objetivas; bem como do próprio conceito de "totalidade", com o qual a crítica podia ser sustentada em nome de uma visão privilegiada do todo social, derivada seja da posição da classe trabalhadora no processo de produção, seja da eliminação da parcialidade das ciências especializadas. Sem mirarmos aqui os detalhes que levam a essa autocrítica, ela toma o caráter de uma crítica imanente à filosofia da práxis quando acrescenta que a assunção prolongada de tais pressupostos levam a um afastamento da teoria em relação à histó- 
ria; em especial, quando aponta que um tal modelo não consegue mais abarcar os processos sociais e as lutas emancipatórias vividas no âmbito do capitalismo tardio (Habermas, 1987; Honneth, 1999; Cohen, 1982; Repa, 2004). E frente a tais rejeições fundamentais, a orientação pela emancipação tem de lidar com um duplo desamparo: de um lado, com a suspensão das certezas que possibilitavam falar da "dominação de classe", sente-se a falta dos critérios que permitam a caracterização de práticas e estruturas sociais como "formas de dominação vigentes", cuja superação dá o sentido e a necessidade de uma crítica social; de outro lado, resta abalada a própria caracterização da perspectiva emancipatória como uma "possibilidade real", tendo ela de se sustentar por recursos outros que aqueles provenientes de uma filosofia da história.

Nos desenvolvimentos contemporâneos da teoria crítica da sociedade, tais problemas têm sido usualmente tratados por meio do recurso a uma reflexão normativa enraizada. A possibilidade de a teoria continuar sustentando seu comprometimento com uma crítica social imanente e não idealista passa a ser alojada em sua capacidade de descortinar os critérios normativos que a possibilitam na própria realidade observada. Com efeito, em "Social Dinamics of Disrespect: situating Critical Theory today", Axel Honeth apresenta a Teoria Crítica como "uma forma particular de crítica normativa”, cujo ponto de vista crítico é ancorado em "possibilidades intramundanas de emancipação" (Honneth, 1999, p.323-324). Em um sentido similar, Iris Young escreve: "Tal como eu a compreendo, a Teoria Crítica é uma forma de reflexão normativa histórica e socialmente contextualizada, [...] a qual projeta possibilidades normativas não realizadas, mas sentidas numa realidade social particular." (Young, 1990, p.6-7). Ao recorrerem a uma reflexão normativa enraizada, tais autores pretendem, ao mesmo tempo, garantir a imanência dos critérios que permitem a crítica social e sustentar o caráter prático da orientação pela emancipação; vale dizer, sob as exigências de um efetivo enraizamento da crítica, a teoria se compromete não apenas com a elaboração conceitual das expectativas normativas veiculadas socialmente, mas também com a análise das condições de seu cumprimento, sem a qual a atitude teórico-normativa não consegue se comprovar como algo além da explicitação de utopias compartilhadas. No cumprimento dessa última exigência, a qual compreende a tarefa de uma constante avaliação sobre as atuais possibilidades e bloqueios à emancipação, a teoria crítica mobiliza conhecimentos de ciências e disciplinas especializadas, não mais com a pretensão de possuir ante elas um ponto de vista cognitivo privilegiado, mas sob a premissa de uma cooperação mesma entre as reconstruções normativas e os saberes aplicados.

Habermas pode ser considerado precursor dessa caracterização normativa da teoria crítica, a qual, segundo ele, sempre precisou se valer de critérios normativos não-explicitados como sua condição mesma de possibilidade (Habermas, 1990, p.51-52). A inscrição dessa tese em Direito e Democracia pode ser encontrada já em seu prefácio:

O colapso do socialismo de Estado e o final da 'guerra civil internacional' colocaram em evidência a falha teórica do partido fracassado: descobriu-se que ele confundira o projeto socialista com o esboço - e a imposição forçada - de uma forma de vida concreta. Todavia, se entendermos 'socialismo’ como protótipo de condições necessárias para formas de vida emancipadas, sobre as quais os próprios participantes precisam entender-se preliminarmente, não é difícil verificar que a autoorganização democrática de uma comunidade jurídica forma o núcleo normativo desse projeto (Habermas, [1992, p.12] 1997, v.1, p.12).

Com essas palavras, Habermas retoma um posicionamento firmado em "Direito Natural e Revolução" e constantemente reafirmado em sua obra: a reprovação veemente ao abandono do direito e das reivindicações democráticas por parte de Marx e do marxismo. Habermas nos lembra que, para além das passagens ambíguas da Crítica à Filosofia do Direito de Hegel e da Crítica ao Programa de Gotha, que afirmam a liberdade como "a transformação do Estado, de 
um órgão superposto à sociedade, num órgão totalmente a ela subordinado" - das quais poder-se-ia retirar a compreensão da "sociedade comunista como a única forma possível de realização da democracia" -, Marx não dá mais nenhuma palavra a respeito da institucionalização dessa mesma liberdade: "Sua imaginação institucional não vai além da ditadura do proletariado prevista para o "período de transição." (Habermas, 1991, p.51). Com base em um nexo funcional supostamente necessário entre dominação de classe e sistema jurídico, Marx e a maior parte do marxismo teria se recusado a incorporar explicitamente qualquer pretensão normativa ligada ao Estado democrático de direito, sendo tal recusa considerada por Habermas uma das deficiências de "maiores consequências práticas” ao projeto marxista, já que teria contribuído, de forma decisiva, para o "desvio" ou a "completa inversão" de suas intenções emancipatórias no âmbito do socialismo de Estado. Para Habermas, o socialismo teria sido interpretado como uma figura historicamente privilegiada da moralidade concreta, na qual os trabalhadores livremente associados, tão logo instaurado o modo de produção correto, teriam sua convivência normalmente harmonizada segundo uma ética própria, estimulada pelo projeto teórico ou mesmo imposta forçadamente por uma vanguarda política. Com a negação da ordem jurídico-democrática, pois, o materialismo histórico teria assumido um caráter tão substantivo a ponto de parecer sustentar que tanto a resposta às questões práticas (i.e., morais, éticas e pragmáticas) supervenientes à revolução, quanto a própria supressão revolucionária da propriedade privada não tivessem necessariamente de recorrer à livre formação da vontade de sujeitos historicamente enraizados. Habermas escreve, entretanto, que, se considerarmos o socialismo, em suas linhas mestras, como a emancipação de condições heterônomas de reprodução material e simbólica da sociedade, segundo a qual indivíduos poderiam se enxergar como os autores de seus destinos particulares e comuns, o núcleo normativo de tal projeto poderia ser encontrado na auto-organização democrática de uma comunidade jurídica.

Esse trecho nos revela, muito antes do que teses a serem defendidas no âmbito de uma exegese marxista rigorosa, dois elementos fundamentais do próprio modelo crítico presente em Direito e Democracia: um novo direcionamento à compreensão de emancipação social, pautado nas condições necessárias a processos de entendimento livre de coerções, e um núcleo normativo centrado nas pretensões radical-democráticas de auto-organização de uma comunidade jurídica. Com efeito, desde sua Teoria da Ação Comunicativa, a emancipação social passa a ser delineada por Habermas em termos de aproveitamento e expansão dos potenciais comunicativos liberados com o advento das sociedades pós-tradicionais modernas, os quais estariam constantemente ameaçados de ser neutralizados pelo avanço dos sistemas econômico e político sobre a base comunicativa do mundo da vida. Dessa maneira, o modelo crítico habermasiano pretende deslocar de sua perspectiva emancipatória a assunção de qualquer modelo substantivo de sociedade justa ou virtuosa, comprometendo-se com a investigação das condições comunicativas necessárias para que os próprios concernidos possam decidir acerca de sua forma de vida concreta mediante processos de entendimento livres de coerções. A Teoria Crítica, pois, não assume aqui o "conteúdo" daquelas soluções históricas a produzir formas de vida emancipadas, as quais pudessem ser realizadas diretamente por meio de uma revolução de caráter definitivo; ela confia tais decisões a uma práxis comunicativa constante de sujeitos histórica e socialmente enraizados, cujos resultados falíveis e sempre reflexivamente modificáveis pretendem expressar acordos alcançados entre si por meio de seu livre convencimento.

Desde Direito e Democracia, essa compreensão discursiva e "dessubstancializada" da emancipação social encontra seu núcleo normativo na pretensão de "auto-organização democrática de uma comunidade jurídica”, a qual 
expressa a expectativa de uma regulação autônoma da vida social por meio de procedimentos deliberativo-decisórios radicalmente inclusivos. De um lado, pois, o procedimento jurídico-democrático exigirá não apenas a distribuição das liberdades políticas e a criação das estruturas institucionais a permitirem que as opiniões, tematizações e os questionamentos de todos os concernidos possam ser apresentados em igualdade de condições nos processos de formação da vontade coletiva, mas também que as contribuições particulares aí apresentadas possam ser consideradas autonomamente produzidas, exigindo, pois, a distribuição de liberdades subjetivas de ação e de condições materiais igualitárias entre todos. De outro lado, por expressar seus resultados segundo a forma coercitiva do direito positivo, a auto-organização democrática envolve não apenas processos de formação da opinião e da vontade, mas também decisões de caráter obrigatório. Com isso, os processos jurídico-democráticos alimentam a expectativa de transformar o poder comunicativo, gerado nas bases sociais do "mundo-da-vida" em imperativos eficazes frente não apenas a seus cidadãos-destinatários, como também aos sistemas econômico e político. Assim, a práxis comunicativa - que, no âmbito da Teoria da Ação comunicativa, apenas era considerada capaz de oferecer "resistência" à expansão da lógica sistêmica em direção ao mundo da vida, delimitando sua área de atuação e preservando formas de interação comunicativamente reguladas - passa a ser considerada capaz de agir sobre o funcionamento dos sistemas instrumentais de ação por meio das instituições democráticas.

\section{A TENSÃO ENTRE FACTICIDADE E VALIDA- $D E$ : da linguagem ao direito}

Tais elementos constitutivos do modelo crítico presente em Direito e Democracia serão desenvolvidos em seus dois capítulos iniciais, nos quais Habermas pretende introduzir a categoria do direito na ótica da teoria do agir comunicativo. Segundo o autor, a guinada linguística ope- rada na filosofia ocidental com Frege e Peirce revelou uma tensão entre facticidade e validade embutida no próprio uso da linguagem cotidiana: tal tensão é encontrada em pressupostos pragmáticos contrafactuais que, embora possuam conteúdos ideais, têm de ser admitidos factualmente por todos os participantes de discursos sempre que eles pretendem entrar em uma argumentação para justificar ou negar pretensões de validade. Todo sujeito que utiliza a linguagem a fim de entender-se com um destinatário qualquer ver-se-ia obrigado a adotar certos pressupostos idealizantes, os quais, embora possam ser unidos ao estoque de problematizações levantadas ao longo da interação comunicativa, permitem dar início a elas e possibilitar processos de aprendizagem social. Habermas nos apresenta, nessas páginas de Direito e Democracia, dois tipos de idealizações necessárias: aquelas ligadas à "generalidade do significado" e à "universalidade das pretensões de validade"; vale dizer, a suposição de que as palavras e os enunciados utilizados pelas partes possuem significados idênticos e a de que as pretensões de validade resgatadas argumentativamente podem ser consideradas justificadas não somente perante os próprios participantes, mas também em relação a todos aqueles que eventualmente participassem da comunicação. Sem esse primeiro tipo de suposição, escreve o autor, não seria possível sustentar a expectativa de falantes entenderem-se sobre algo no mundo e nem de superar, no interior do próprio discurso, seus eventuais mal-entendidos:

A idealidade da generalidade do significado marca os contextos do agir comunicativo na medida em que os participantes não conseguem formular a intenção de entender-se entre si sobre algo no mundo, nem atribuir às expressões utilizadas significados idênticos, caso lhes seja vedado apoiar-se numa linguagem comum (ou traduzível). E os mal-entendidos só podem ser descobertos como tais quando esta condição estiver preenchida. A suposição da utilização de expressões linguísticas com significado idêntico pode às vezes parecer errônea na perspectiva do observador e, inclusive, parecerá sempre errônea à luz do microscópio dos etnometodólogos; entretanto, tal pressuposto é necessário, ao me- 
nos contrafactualmente, para todo uso da linguagem voltada ao entendimento. (Habermas, [1992, p. 35] 1997, v.1, p.38)

Sem o segundo tipo de suposição, por sua vez, não seria possível falar em algo "verdadeiro" ou "correto" para além dos contextos de comunicações atuais desempenhadas por atores determinados. Para Habermas, a sustentação das pretensões de "verdade proposicional" e de "correção normativa" exigiria a suposição de que os argumentos mobilizados para seu resgate fossem também aceitos em face de uma comunidade interpretativa ampliada universalmente. E, embora a suposição idealizante de um auditório universal nunca possa se comprovar factualmente, ela permite que ações ligadas ao contexto sejam orientadas em nome das pretensões de verdade e correção intersubjetivamente partilhadas, além de exigir, segundo os termos de uma "coerção transcendental fraca", que tais orientações estejam sempre abertas a novos argumentos e problematizações.

O momento ideal de incondicionalidade está enraizado nos processos de entendimento factuais, porque as pretensões de validade põem à mostra sua dupla face de Jano: enquanto pretensões, elas ultrapassam qualquer contexto; no entanto, elas têm que ser colocadas aqui e agora, caso contrário não serão capazes de ser portadoras de um acordo capaz de coordenar a ação pois não existe para isso um contexto zero. A universalidade da aceitabilidade racional asserida explode todos os contextos; entretanto, somente a aceitação obrigatória in loco pode fazer das pretensões de validade trilhos para uma prática cotidiana ligada ao contexto. (Habermas, [1992, p.37] 1997, v.1, p.39)

Para Habermas, assim, a assunção de tais pressupostos idealizantes, ligados às condições de uma comunicação sem entraves, não apenas possibilita comunicações factuais, como também permite que as distorções comunicativas aí encontradas possam ser constatadas e criticadas pelos próprios falantes. Nesse sentido, escreve mais uma vez Marcos Nobre:

Sendo um tipo de orientação da ação efetivamente presente na realidade das relaçôes sociais, a ori- entação para o entendimento só é possível, entretanto, porque projeta condições ideais em que não haveria qualquer obstáculo à plena comunicação entre os interlocutores. Nesse sentido, diz Habermas, tais condições ideais são, por paradoxal que possa parecer, condições de comunicações reais no mundo. [...] Salta aos olhos, entretanto, que condições como essas jamais se cumprem no mundo real das relações sociais, em que as assimetrias e dessimetrias entre os sujeitos são a regra e não a exceção. Mas esse é justamente o argumento de Habermas: ao orientar sua ação para o entendimento, os sujeitos antecipam necessariamente tais condições ideais, pois sem elas não seria possível uma ação comunicativa; simultaneamente, entretanto, tais condições necessárias não são cumpridas, o que permite, por sua vez, que sejam detectadas todas as distorções da comunicação - aqueles obstáculos que impedem a cada vez a plena realização de uma ação comunicativa. Para que a comunicação possa se dar, essas condições ideais têm de ser antecipadas em situações reais de ação, o que significa que essa antecipação encontra-se inscrita na vida social concreta. Com isso, Habermas pode simultaneamente fornecer uma solução para o ancoramento real da emancipação na configuração social atual e estabelecer um parâmetro crítico para avaliar tanto o conhecimento produzido quanto situações sociais concretas, já que o potencial comunicativo inscrito na vida social jamais se realiza plenamente. (Nobre, 2004, p.56-57)

Importante notar, assim, que não se trata esta de uma tensão a ser integralmente superada: Habermas insiste que a identificação das funções pragmáticas exercidas por tais pressupostos idealizantes não deve ser interpretada como a assunção teórica de um estado final almejável; uma completa correspondência dos elementos constitutivos da tensão entre facticidade e validade embutida na linguagem sugeriria o alcance de uma "linguagem última, de uma interpretação definitiva, de um saber irrevidável”, na posse dos quais "qualquer nova comunicação poderia mesmo ser considerada supérflua”. No que se refere às suposições contrafactuais antes apresentadas, o nivelamento completo da tensão entre facticidade e validade poderia sugerir, por exemplo, que não existissem mais ressignificações possíveis para expressões e enunciados linguísticos, ou questionamentos contextuais legítimos para pretensões de validade que reclamam universalidade. Por isso, Habermas explicita 
que "o resgate discursivo de pretensões de validade (isto é, a pretensão de que se cumpram as condições para a validade de um enunciado) deve ser considerado como um processo metacrítico contínuo de enfraquecimento das objeções." (Habermas, 1998, p.418).

Após introduzir a tensão entre facticidade e validade embutida na linguagem, Habermas nos diz que essa tensão "emigra" para o mundo dos fatos sociais na medida em que indivíduos são socializados linguisticamente; com isso, ela passa a ser compreendida como um momento da facticidade social, vale dizer, como um elemento da prática comunicativa através da qual se reproduzem cotidianamente as formas de vida:

Os argumentos devem sua força racionalmente motivadora a uma relação interna com a dimensão do significado e da validade de expressões linguísticas. E constituem naturalmente uma faca de dois gumes, porque tanto podem fortalecer convicções, quanto estremecê-las. Com elas, a tensão entre facticidade e validade que reside na linguagem e no seu uso, introduz-se na sociedade (Habermas, [1992, p. 54] 1997, v.I, p. 57).

Sempre que sujeitos coordenam suas ações por meio do uso da linguagem voltado ao entendimento, eles levantam pretensões de validade criticáveis, as quais têm de ser resgatadas por meio de argumentos aceitos intersubjetivamente. Essa forma particular de socialização, chamada por Habermas de "ação comunicativa", é responsável por um tipo de integração profundamente instável, já que incorpora em si aquela tensão entre facticidade e validade própria da linguagem, encontrando-se, pois, constantemente ameaçada por um imenso leque de problematizações possíveis. Ao mesmo tempo, embora a integração linguisticamente mediada seja considerada profundamente instável, ela é apresentada aqui como a única forma de integração social não violenta, porque pautada na coordenação voluntária de planos de ação e na aceitação racionalmente motivada de normas e suposições de fatos (Habermas, [1992, p. 33] 1997, v.1, p.36).

Segundo Habermas, portanto, a análise dos pressupostos pragmático-linguísticos nos conduz a uma situação paradoxal: a forma mais própria de socialização não-coercitiva, a saber, aquela baseada no entendimento comunicativo, é, ao mesmo tempo, considerada uma forma de integração social extremamente instável; vale dizer, uma forma de integração incapaz de estabilizar por si mesma o profundo risco de dissenso e desagregação que lhe é típico. E, dessa forma, para continuarmos perseguindo os potenciais de integração comunicativa sem negligenciar suas debilidades características, "impõe-se uma intervenção reconstrutiva, a fim de explicar o modo de surgimento da integração social sob condições de uma socialização instável, que opera com suposições contrafactuais, permanentemente ameaçadas". Assim, antes de avaliar as possibilidades de uma integração comunicativa nas sociedades atuais, Habermas se vale de três passos teóricos subsequentes: em primeiro lugar, o profundo grau de dissenso da integração comunicativa, que se revelou a partir da análise pragmático-linguística empreendida, é parcialmente reduzido quando alcança o âmbito sociológico de análise do mundo da vida: ... o alto risco de dissenso, alimentado a cada
passo através de experiências, portanto, através
de contingências repletas de surpresas, tornaria
a integração social através do uso da linguagem
orientado pelo entendimento inteiramente
implausível se o agir comunicativo não estives-
se embutido em contextos do mundo da vida, os
quais fornecem apoio através de um maciço pano
de fundo consensual (Habermas, [1992, p. 38]
1997, v.I, p. 40).

Assim, o mundo da vida, compreendido como a esfera de reprodução simbólica da sociedade, seria constituído por um pano de fundo consensual no qual se desenvolvem as práticas de entendimento a partir do horizonte de convicções comuns habitualmente não problematizadas; vale dizer, de um estoque de saber não explícito que torna possível a ação comunicativa ao inscrevê-la em um campo de certezas imediatas, as quais pressupomos sem a plena consciência de seu uso. Com isso, o risco de dissenso é significativamente removido na medida em que "na 
prática do dia a dia, a inquietação ininterrupta através da experiência e da contradição, da contingência e da crítica, bate de encontro a uma rocha ampla e inamovível de lealdades, habilidades e padrões de interpretação consentidos." (Habermas, [1992, p.38] 1997, v.1, p.40).

$\mathrm{O}$ acirramento da perspectiva históricosociológica nos aponta, em segundo lugar, para uma ultraestabilização da tensão entre facticidade e validade, derivada não apenas das certezas intuitivas do mundo da vida, mas de sua ligação com garantias metassociais conferidas por autoridades de cunho religioso. Para Habermas, as sociedades tradicionais se caracterizavam não apenas por formas de vida homogêneas, que já se encontravam bem imunizadas contra problematizações por meio das convicções quase unânimes de um mundo da vida pouco diferenciado, como também por autoridades impositivas que revestiam o complexo cristalizado de convicções com o poder factual de coações sancionadoras:

O jogo de narrativas místicas e de ações rituais pode mostrar por que esse saber só pode ser tematizado com reservas. Restrições à comunicação, determinadas cerimonialmente, protegem contra problematizações a validade autoritária dos conteúdos descritivos, valorativos e expressivos que se entrelaçam formando uma síndrome. $\mathrm{O}$ complexo cristalizado de convicções afirma um tipo de validade revestida com o poder do factual. De sorte que a fusão entre facticidade e validade não se realiza no modo de uma familiaridade originária, através das certezas que de certa forma carregamos nas costas na forma de mundo da vida, mas no modo de uma autoridade ambivalente que vem ao nosso encontro de forma impositiva. (Habermas, [1992, p.40] 1997, v.1, p.42-43)

No contexto das sociedades tradicionais, portanto, não havendo para os próprios atores uma diferenciação clara entre a facticidade da autoridade impositiva de ordens coercitivas e sua aceitabilidade fundada em convicções, autoridade e validade permaneceriam amalgamadas segundo a égide de uma força normativa dos fatos.

Por fim, Habermas escreve que os processos modernos de complexificação social nos remetem à pluralização de mundos da vida antes ho- mogêneos, ao declínio das garantias de estabilidade metassociais oferecidas por autoridades religiosas e à diferenciação funcional da sociedade em sistemas de ação orientados pelo interesse estratégico. É, pois, com a diluição da sociedade tradicional que são liberados os potenciais comunicativos capazes de dar vazão ao exercício ampliado de uma crítica intramundana e a uma integração linguística pautada no livre convencimento. Entretanto, a liberação de tais potenciais comunicativos não consegue, por si mesma, preencher as condições para seu devido aproveitamento: em um mundo profanizado e pluralizado em diferentes formas de vida, as certezas intuitivas do mundo da vida mostram-se cada vez mais frágeis e expostas à problematização, não sendo capazes de, sozinhas, estabilizar de maneira prolongada os riscos de dissenso e de desagregação da integração comunicativa. Ao mesmo tempo, a integração comunicativa se vê obrigada a conviver com duas outras formas de integração sistêmica oferecidas pelo Estado e pela economia, baseadas elas nos meios nãocomunicativos do poder e do dinheiro. Dessa forma, aquele "paradoxo" da integração comunicativa, apresentado anteriormente segundo a simples análise dos pressupostos linguístico-pragmáticos da comunicação cotidiana, é expresso agora no seguinte problema:

... como integrar socialmente mundos da vida em
si mesmos pluralizados e profanizados, uma vez
que cresce simultaneamente o risco de dissenso
nos domínios do agir comunicativo desligado de
autoridades sagradas e instituições fortes? Após
a descrição dessa cena, parece que a necessidade
crescente de integração, nas modernas socieda-
des econômicas, sobrecarrega a capacidade de
integração do mecanismo de entendimento dis-
ponível, quando uma quantidade crescente de
interações estratégicas, imprescindíveis para a
estrutura social, são liberadas. (Habermas, [1992,
p.43-44 ] 1997, v.1, p.46).

É em face de tal delineamento de problemas que o direito será apresentado por Habermas como uma forma de estabilização da integração linguística que permite manter livres (ou "nãoconfinados") os potenciais críticos do mecanismo comunicativo: 
... a positivação completa do direito, antes apoiado no sagrado e entrelaçado com a eticidade convencional, vai apresentar-se como uma saída plausível para esse paradoxo, como um mecanismo com o qual uma comunicação não-circunscrita pode aliviar-se das realizações de integração social sem se desmentir: através dele, cria-se um sistema de regras que une e, ao mesmo tempo, diferencia ambas as estratégias, a da circunscrição e a da liberação do risco do dissenso embutido no agir comunicativo (Habermas, [1992, p. 56] 1997, v.I, p. 59).

Para Habermas, pois, o direito aparece na modernidade como a forma de assegurar as expectativas de comportamento em contextos póstradicionais, fazendo uso da regulação coercitiva do comportamento e, com isso, separando a faticidade e a validade amalgamadas anteriormente nos aspectos de cumprimento das normas. Quando as exigências normativas passam a se dirigir para o comportamento dos destinatários, sua validade, compreendida como aceitação no campo das convicções internas, desligase da simples faticidade de sua imposição externa, passando a poder ser questionadas mesmo por aqueles que as cumprem formalmente. Segundo Habermas, a positivação moderna dos direitos subjetivos coloca explicitamente à disposição do destinatário uma escolha sobre a perspectiva de cumprimento da norma: elas passam a poder ser cumpridas como meras delimitações factuais presentes no leque de dados do ator que age estrategicamente, atuando como uma força que o induz a adaptar objetivamente seu comportamento em face de uma ameaça de sanção; ou como uma força social integradora para o ator que age pela convicção de sua aceitabilidade, a qual só é possível segundo a sustentação intersubjetiva de suas pretensões de validade. Por um lado, essa dupla perspectiva estabiliza as expectativas de comportamento por meio de sanções e, por outro, possibilita a exposição de normas e valores ao exame crítico. E tal liberação dos mecanismos comunicativos de reflexão e crítica traz consequências diretas para coordenação do comportamento por meio do direito, já que permite que seja ligada à imposição do direito positivo uma expectativa de legitimidade a ser cumprida com a criação de procedimentos de formação democrática da vontade, segundo os quais "as leis coercitivas devem comprovar sua legitimidade como leis da liberdade no processo de legislação" (Habermas, [1992, p. 47] 1997, v.I, p. 50).

Para Habermas, pois, a maneira particular com que o direito moderno incorpora a tensão entre facticidade e validade explica por que ele pode ser considerado aqui um instrumento capaz de aliviar os sobrecarregados processos de entendimento das tarefas de integração social sem anular, em princípio, a liberação dos mecanismos comunicativos: de um lado, a positividade do direito estabiliza expectativas de conduta fazendo uso de coerções impostas faticamente a seus destinatários, sendo tal imposição considerada não uma expressão de mandamentos sagrados ou de leis naturais imutáveis, mas um fragmento da realidade social produzido artificialmente, o qual só existe até segunda ordem, "já que pode ser modificado ou colocado fora de ação em qualquer um de seus componentes singulares" (Habermas, [1992, p.57] 1997, v. I, p.60). De outro lado, é a pretensão de legitimidade que "empresta duração a determinadas normas para que se oponham à possibilidade presente de virem a ser declaradas sem efeito", sendo tal pretensão alojada na expectativa de terem sido criadas pelos próprios destinatários segundo um livre acordo motivado argumentativamente.

Além disso, o direito possibilita não apenas estabilizar as expectativas de comportamento geradas comunicativamente, como também a quantidade crescente de interações estratégicas. Habermas escreve, pois, que o direito mostra-se ligado "às três fontes de integração social"; vale dizer, ele apresenta-se como um medium de integração, ligado não apenas às fontes próprias do agir comunicativo, como também às fontes sistêmicas do mercado e do poder administrativo, as quais "coordenam as ações de forma objetiva, como que por detrás das costas dos participantes da interação.” De um lado, pois, o direito se mantém ligado às fontes de integração comu- 
nicativa através, principalmente, dos processos de formação democrática da vontade, abertos aos argumentos e problematizações de todos os eventuais interessados. De outro, as instituições do direito privado e público possibilitam o estabelecimento de mercados e a organização do poder de Estado, "pois as operações do sistema administrativo e econômico [...] completam-se em formas do direito." (Habermas, [1992, p. 59] 1997, v.1, p.61-62).

Para Habermas, é essa ambivalência do direito, ligado tanto ao mundo da vida quanto aos sistemas funcionais de ação, que o permite exercer funções em face de toda a sociedade. Entretanto, o autor ressalta que, em sua "ambivalência", o direito não deixa de possuir, sob um ponto de vista crítico, um caráter extremamente "ambíguo". Com efeito, de um lado, ele abre canais para que os imperativos provenientes de interações comunicativas alcancem os sistemas econômico e político com a pretensão de seu direcionamento legítimo. De outro, entretanto, os sistemas de ação podem se servir da força legitimadora da forma jurídica a fim de disfarçar uma imposição meramente factual dos meios de integração ligados ao poder e ao dinheiro:

Como meio organizacional de uma dominação política, referida aos imperativos funcionais de uma sociedade econômica diferenciada, o direito moderno continua sendo um meio extremamente ambíguo da integração social. Com muita frequência o direito confere a aparência de legitimidade ao poder ilegítimo. À primeira vista, ele não denota se as realizações de integração jurídica estão apoiadas no assentimento dos cidadãos associados, ou se resultam de mera autoprogramação do Estado e do poder estrutural da sociedade; tampouco revela se elas, apoiadas neste substrato material, produzem por si mesmas a necessária lealdade das massas. (Habermas, [1992, p.59-60] 1997, v.1, p.62)

\section{OS MOMENTOS RECONSTRUTIVOS}

Em face da recorrência com que o direito e a formação democrática da vontade se apresentam propensos a ceder à pressão profana dos imperativos funcionais e a disfarçar, com uma aparência de legitimidade, a imposição factual da dominação política e econômica, uma teoria que se volta aos potenciais de entendimento e crítica contidos no Estado democrático de direito não pode assumir meramente a observação positivista de seus insucessos, limando-se a desmentir suas pretensões idealizantes em face do funcionamento corriqueiro do poder; tampouco a postura de um observador idealista, o qual, identificando as intuições normativas que habitam a autocompreensão do direito, presta-se à tarefa de afirmá-las a todo custo, em relativo desprezo a uma realidade que não as condiz plenamente. Por isso, Habermas assume a estratégia de partir da tensão entre facticidade e validade interna ao sistema de direitos, a qual permite reconstruir, segundo os termos da teoria do discurso, as pretensões normativas nascidas na autocompreensão do direito, para depois passar à analise da tensão externa entre as pretensões normativas de ordens democrático-constitucionais e a facticidade de seu contexto social, com a qual se pode avaliar em que medida tais pretensões se apresentam como potencialidades inscritas nas sociedades complexas atuais.

Delineia-se, assim, a divisão de duas grandes abordagens teóricas que irão marcar a estrutura de Direito e Democracia. De um lado, a reconstrução interna da tensão entre facticidade e validade, traduzida como uma tensão entre positividade e legitimidade a permear os códigos jurídicos e a organização interna do Estado democrático de direito; de outro lado, a reconstrução externa, focada na tensão juridicamente mediada entre as pretensões sociais geradas comunicativamente e o funcionamento dos sistemas funcionais de ação. Para Habermas, essa estratégia é justificada em sua intenção de iniciar uma análise do Estado democrático de Direito no interior do campo crítico:

Uma teoria crítica da sociedade não pode limitar-se à descrição da relação entre norma e realidade servindo-se apenas da perspectiva do observador. Antes de retomar esta tensão externa 
entre as pretensões normativas de ordens democrático-constitucionais e a facticidade de seu contexto social, eu desejo reconstruir, nos próximos capítulos, a autocompreensão destas ordens jurídicas modernas. E tomo como ponto de partida os direitos que os cidadãos têm que atribuir uns aos outros, caso queiram regular legitimamente sua convivência com meios do direito positivo. Esta formulação deixa entrever que existe uma tensão entre facticidade e validade permeando o sistema de direitos em sua totalidade, característica do modo ambivalente de validade jurídica. (Habermas, [1992, p. 109] 1997, v.1, p.113)

Como primeira etapa reconstrutiva, Habermas procura penetrar o interior da esfera jurídica em diversas de suas vias de acesso, buscando, em cada uma delas, reelaborar a leitura dos princípios que orientam o funcionamento do Estado democrático de direito em suas funções de criação e aplicação normativa. Por que não basta ao autor a mera identificação desses princípios normativos? Isto é, por que seria necessária sua reconstrução segundo a teoria do discurso? A resposta a essa pergunta nos leva a compreender que, nas próprias elaborações teóricas da autocompreensão do direito - cumpridas historicamente por disciplinas e campos investigativos distintos, como a dogmática jurídica, a filosofia do direito, a hermenêutica jurídica e a sociologia do direito -, já se imiscuem bloqueios e imunizações discursivas que impedem o pleno aproveitamento dos potenciais comunicativos liberados na modernidade. Quando Habermas dirige o empreendimento reconstrutivo à produção teórico-jurídica, isso significa que ela mesma é responsável pela racionalização e justificação de modos limitados de se operar a práxis jurídica, os quais não condizem com suas potencialidades mais amplas.

A chamada "reconstrução interna” envolve um âmbito extenso de temas, tópicos e discussões que perpassam a compreensão do direito, os quais não podem ser todos abarcados aqui. Explicitaremos a maneira como a crítica é operada nessa etapa da obra a partir de um de seus objetos mais destacados, a saber, a reconstrução das duas formas de autonomia que se constitu- em juridicamente. As autonomias privada e pública são apresentadas ali como as únicas ideias capazes de legitimar o direito em condições póstradicionais, sendo, entretanto, alojadas pela teoria do direito e pela filosofia política modernas num embate recíproco que leva à submissão alternada de cada uma delas. Para o autor, pois, a modernidade jurídica e filosófica teria encontrado na noção de "autonomia” o fundamento último do Estado democrático de direito, sem que, no entanto, tivesse conseguido produzir formulações desse conceito capazes de evitar a imagem de um conflito não solucionado entre seus momentos internos. Essa tensão entre as autonomias pública e privada seria responsável não apenas por compreensões equivocadas do direito - incapazes de descrever, em sua plenitude, a autonomia que se instaura juridicamente-, como também formas diferentes de autoritarismo - por sempre reprimirem um desses âmbitos da liberdade em benefício do outro (Silva, 2008).

Para o autor, essas oposições teriam origem em resquícios metafísicos preservados pela herança compartilhada da filosofia do sujeito, a qual apenas altera as dimensões de uma consciência que opera monologicamente. Nesse sentido, o jogo de forças entre autonomia privada e pública seria sempre resolvido em nome do sujeito considerado, seja o sujeito individual culturalmente desenraizado, cuja vontade antecede os contextos intersubjetivos no qual se encontra situado, seja o macrossujeito coletivo, representado pela ideia de um "povo" dotado de homogeneidade ética. É importante salientar que encontramos, em cada uma dessas formulações, bloqueios comunicativos significativos: de um lado, os conteúdos da autonomia privada, entendidos como direitos inatos e exercidos de modo atomista, são apartados da crítica e do escrutínio público. Ao conceber as garantias jurídicas à individualidade autônoma em termos estritamente restritivos e fixar seus conteúdos como direitos pré-políticos, o pensamento moderno teria transformado a autonomia privada em um princípio de conservação acrítica de cer- 
tas relações interpessoais existentes, impedindo que as injustiças cometidas no interior dos âmbitos da vida social eleitos como "privados" pudessem vir a ser discutidas e modificadas publicamente. De outro lado, a figura holística de um povo dotado de homogeneidade ético-cultural confere ao ideal de autogoverno um pressuposto não apenas implausível do ponto de vista sociológico, como sobremodo repressivo, já que evita, de antemão, o dissenso existente entre membros de uma mesma coletividade, legitimando políticas de assimilação das minorias e de preservação forçada da pureza cultural.

Habermas propõe um modo próprio de interpretar o conceito de autonomia, seguindo a linha da teoria do discurso. Seu princípio do discurso ("princípio D"), o qual concentra as exigências de racionalidade de discursos práticos, exige que toda norma de ação possa encontrar o assentimento dos possíveis atingidos como participantes de discursos racionais. Dessa forma, a autonomia é ligada à formação discursiva da opinião e da vontade, representando um esforço cooperativo na tomada de posições intersubjetivamente informada acerca de questões práticas. Com isso, o núcleo normativo é transferido para a práxis comunicativa, isto é, para processos intersubjetivos de entendimento em que o livre fluxo de argumentos e contribuições substitui a posição central que as concepções monológicas de sujeito possuíam anteriormente na construção teórica moderna. A partir desse fundamento discursivo comum, a autonomia pública e a privada serão reelaboradas de tal forma que os antigos conflitos travados entre si sejam substituídos por uma relação de complementaridade recíproca.

Em sua reconstrução discursiva, a autonomia privada passa a representar as liberdades subjetivas que garantem um âmbito de interação social no qual os sujeitos de direito não são obrigados a prestar esclarecimentos ou justificações públicas para suas ações. Nesse sentido particular, a autonomia privada protegeria a "liberdade de arbítrio" do sujeito de direito, autorizando-o a evitar os contextos comunicativos ou a utilizar a linguagem de forma meramente estratégica, tendo em vista o melhor cumprimento de seus planos de ação. Essa autorização da ação, entretanto, não deve ser entendida em termos meramente negativos. Ela não significa a exclusão dos contextos comunicativos cotidianos. Ao contrário, a possibilidade de arbítrio representa a garantia de que o sujeito de direito possa decidir as circunstâncias em que fará uso da linguagem voltada ao entendimento acerca das orientações axiológicas e formas de vida mais justificáveis para si mesmo. Nesses termos, Habermas nos diz que a autonomia privada protege a "liberdade ética" do sujeito de direito individual, a qual representa sua liberdade para formular as próprias concepções de bem e de integrá-las em narrativas pessoais tendentes à formação de um projeto de vida individual. Dessa maneira, a autonomia privada passa a ser delineada como a liberdade de arbítrio e a liberdade ética garantida por direitos subjetivos privados, sendo essas duas formas de liberdade (negativa e positiva) constituídas por diferentes possibilidades de uso da linguagem atribuídas ao sujeito de direito.

Como vimos, entretanto, o princípio do discurso prescreve que os próprios concernidos produzam as normas de ação que regulam seu comportamento. Com isso, ele impede que os direitos que configuram substancialmente a autonomia privada sejam estabelecidos a priori pelo teórico, exigindo uma nova dimensão da autonomia vinculada à participação dos cidadãos em processos de formação coletiva da vontade. Nesse ponto, a teoria do discurso exige uma despersonalização da ideia de autogoverno em direção a uma compreensão procedimental de autonomia pública. Com efeito, a legitimidade do autogoverno democrático deixa de repousar na vontade uniforme de um povo, sendo alojada em procedimentos deliberativos nos quais as vozes díspares de todos os concernidos possam ser igualmente consideradas e em que a gênese da vontade coletiva possa ser produzida segundo a livre aceitação dos melhores argumentos. Nesse sentido, ela obriga a positivação de liberdades à participação 
política dos cidadãos em todos os momentos relevantes da produção legislativa. Essa compreensão discursiva de autonomia pública implica, de maneira recíproca, um compromisso necessário com as liberdades individuais. Por estar associada à geração de procedimentos deliberativos racionais, a autonomia pública precisa contar com a garantia de que os sujeitos sejam suficientemente independentes e que as contribuições apresentadas publicamente sejam produzidas sob condições não-coagidas de formação da opinião e da vontade individual. Tais exigências, como vimos, nos remetem à autonomia privada, a qual é constituída por liberdades subjetivas que protegem o sujeito de direito contra o controle e a fiscalização de suas convicções internas, permitindo-lhe avaliar criticamente o saber teórico e o prático que lhe são apresentados, em vista de uma formulação independente de suas próprias visões de mundo.

Nesses termos, a autonomia pública e a privada não apenas possuiriam um fundamento discursivo comum, como também seriam marcadas por uma relação de "pressuposição recíproca”; isto é, compartilham um nexo conceitual que impede a formulação de uma sem a afirmação simultânea da outra. Esse nexo necessário entre os dois momentos da autonomia jurídica revela aquilo que Habermas chama de "cooriginaridade". Essa noção marca a constituição simultânea entre autonomia pública e privada, sendo que suas referências recíprocas, ao invés de representarem uma "falácia teórica”, um "regresso ao infinito", denotam um processo contínuo da práxis política em busca do esclarecimento público de conflitos sociais e da modificação de situações jurídicas que representem barreiras à plena autonomia dos membros da comunidade. Para o autor, o fundamento normativo do código de direitos não pode ser encontrado isoladamente na proteção da individualidade autônoma, tampouco na autoridade da vontade coletiva. Caso cidadãos pretendam regular legitimamente suas vidas por meio do direito, a proteção da privacidade não pode ser produzida sem seu de- vido esclarecimento e convencimento públicos. $\mathrm{E}$, igualmente, as decisões da vontade coletiva não podem suprimir a livre formação da vontade individual, permitindo que toda configuração concreta de direitos continue aberta a percepções críticas e reformulações reflexivas.

Entretanto, ao pretender reelaborar as intuições normativas presentes nos desenvolvimentos modernos do pensamento jurídico-filosófico, Habermas ainda não consegue escapar das limitações normativistas que lhes são próprias. É verdade que a reconstrução interna já faz uso de elementos norteadores de sua teoria da modernização social - os quais enxergam, no advento histórico de sociedades pós-tradicionais, a liberação dos potenciais comunicativos necessários às diferentes modalidades de autonomia jurídica - e que a gênese de seus conceitos fundamentais é realizada em atenção à facticidade de uma forma jurídica observada na maior parte das modernas codificações de direitos. Tais considerações já indicam um afastamento da reconstrução normativo-conceitual habermasiana em relação a fundamentações teóricas desprendidas de seus contextos de surgimento. Entretanto, elas são ainda incapazes de avaliar em que medida as pretensões normativas do direito encontram sua inscrição em meio à complexidade social contemporânea, bem como diagnosticar a natureza de seus principais bloqueios ou distorções. Para Habermas, as limitações de uma perspectiva teórica que opera segundo uma ótica interna aos códigos jurídicos apenas podem ser superadas em atenção a disciplinas voltadas à base social dos processos políticos empiricamente observáveis, as quais permitem um diagnóstico sobre as condições atuais para o cumprimento de um projeto democrático pautado na autonomia dos cidadãos. Trata-se, portanto, de passar a um segundo passo reconstrutivo, focado na tensão entre as pretensões normativas socialmente elaboradas e o funcionamento hermético do poder.

Na reconstrução externa, Habermas parte daquilo que considera ser o diagnóstico compartilhado por todos os modelos realistas da socio- 
logia política contemporânea, o qual aponta para o completo fechamento do sistema político institucional aos fluxos comunicativos oriundos da sociedade civil. Em seu formato melhor acabado, a "Teoria dos Sistemas", a formação democrática da vontade é apresentada como um processo inteiramente solapado pela pressão anônima de imperativos funcionais: o centro de gravidade da política é alojado não apenas nas instituições formais do Estado, mas precisamente em suas instâncias administrativo-burocráticas. Todo tipo de demanda vinda de fora do aparato burocrático seria acomodada como parte de seu "entorno", podendo ali tão somente gerar "irritações" que o levam a novas atividades de autoprogramação. Apesar de denunciar a incapacidade de os modelos realistas comprovarem seus inúmeros pressupostos teóricos segundo os próprios termos explicativos adotados, Habermas não recusa seu diagnóstico integralmente. A crítica se impõe aqui essencialmente ao caráter $l i$ mitado de seu universo explicativo. Ao procurar neutralizar qualquer referência normativa em sua caracterização do sistema político, a teoria dos sistemas não deixaria de recair em profundas falhas descritivas: ela falharia justamente em perceber a normatividade que acompanha o funcionamento dos processos democráticos na medida em que se instauram segundo o medium do direito. Nesse sentido, escreve o autor que "uma teoria dos sistemas que expeliu de seus conceitos qualquer resquício de normatividade, torna-se insensível em relação aos freios normativos contidos no fluxo de poder regulado pelo Estado de direito." (Habermas, [1992, p.406] 1997, v.2, p.64).

O diagnóstico realista, pois, seria parcial na medida em que desconsidera formas de resistência à autoprogramação do sistema político, as quais são encontradas pelo autor em práticas de desobediência civil, na proliferação de movimentos sociais e, fundamentalmente, na constituição de esferas públicas independentes da agenda política oficial. Embora tais formas de resistência sejam com frequência obliteradas pelo exercício rotineiro do poder burocrático, elas não são consideradas por Habermas focos isolados ou casuais. Com efeito, o caráter ambivalente do direito moderno, apresentado na reconstrução interna nos termos de uma tensão entre a positividade da norma e suas exigências de legitimidade, permite que ele seja apresentado aqui como um mediador entre as operações do sistema político e os fluxos comunicativos oriundos do mundo da vida. Para Habermas, quando os sistemas de ação institucionalizam juridicamente suas estruturas de funcionamento, eles assumem, mesmo que a contragosto, as expectativas normativas vinculadas ao medium do direito, as quais os obrigam a se abrirem a exigências de legitimidade veiculadas na linguagem não-especializada do mundo da vida. Assim, a mencionada resistência à autoprogramação burocrática do sistema político pode ser apresentada como uma contratendência da formação política da vontade que parte da sociedade em direção ao Estado, possibilitada pela interligação mesma entre o poder político e a gênese democrática do direito.

Parece que o saber regulatório requerido não consegue mais penetrar nas capilares de um processo de comunicação entrelaçado horizontalmente, aberto osmoticamente e organizado de modo igualitário. Tais evidências, porém, não devem fazer esquecer a circunstância de que o desacoplamento da regulação política do processo parlamentar e a emigração dos temas para fora das arenas públicas não acontecem sem resistência. Pouco importa a versão, nem o tipo de constelação: a questão democrática sempre consegue entrar na agenda. [...] Se partirmos da premissa de que o sentido próprio do medium do direito, com o qual se liga internamente o poder político, nos força a admitir uma gênese democrática do direito, veremos que essas tendências opostas não acontecem por acaso. (Habermas, [1992, p.389] 1997, v.2, p.48)

Para Habermas, é na avaliação dessa possibilidade de inversão dos fluxos do poder burocrático que repousaria "o sentido crítico de uma sociologia da democracia que trabalha de modo reconstrutivo", a qual procura ser desenvolvida à luz dos estudos de Bernhard Peters. Peters descreve a formação política da vontade segundo um modelo que distingue "centro" e "periferia". 
Segundo essa caracterização, o centro do sistema político é composto por instituições decisórias que permitem uma redução significativa da complexidade das deliberações públicas (devido a uma seleção autorizada dos temas e de uma divisão interna do trabalho organizada segundo competências legais) e imprimem facticidade aos resultados da deliberação por meio da coerção estatal. A periferia, por sua vez, seria composta por fluxos comunicativos não-institucionalizados, capazes de captar os problemas sociais com a sensibilidade e a linguagem específica dos próprios atingidos.

Não é a mera diferenciação entre centro e periferia que interessa particularmente a Habermas, mas sim as análises sobre as possibilidades de se inverter o fluxo de poder na direção não-habitual da periferia ao centro; vale dizer, de romper com o funcionamento normalizante do sistema político em nome de impulsos renovadores provenientes da periferia. Segundo Peters, a rotina de funcionamento do sistema político é marcada por processos endógenos operacionalizados pelos códigos próprios da administração, da justiça e do parlamento. Em seu modo rotineiro de operar, o centro da política não apenas se fecha contra impulsos vindos de fora, como também vicia as próprias estruturas periféricas de formação da opinião com sua agenda pré-fabricada de problemas, imprimindo uma direção centrífuga aos fluxos de formação do poder. A formação política da vontade apenas toma a direção que parte da periferia ao centro em casos excepcionais, marcados por crises de legitimidade do sistema político. Em momentos de crise, pois, a legitimidade das decisões do centro da política torna-se débil, ainda que levadas a cabo de acordo com competências formalmente atribuídas. E, embora tais crises sejam internas ao sistema político, as investigações de Peters apontam para a possibilidade de serem "geradas" pela periferia e "aproveitadas" por ela para a incursão de seus fluxos comunicativos próprios. Ao final, o autor tende ainda a relativizar o caráter "excepcional" dos contextos de crise, assumindo que a crescente especialização dos sistemas funcionais de ação gera uma necessidade de integração cada vez maior, a qual "pereniza as crises e acelera os processos de aprendizagem” (Peters, 1993).

Para Habermas, a compreensão das dimensões periféricas de formação democrática da vontade e de suas condições de influir ativamente no sistema político nos remete à consideração de diferentes estruturas comunicativas enraizadas na sociedade civil. De um lado, a esfera pública é apresentada como um conjunto de fluxos comunicativos de horizontes abertos, permeáveis e deslocáveis, adequados à comunicação de conteúdos, opiniões e tomadas de posição entre públicos amplos e dispersos; nela, os fluxos comunicativos são filtrados e sintetizados, a ponto de se condensarem em opiniões públicas enfeixadas em temas específicos, fornecendo razões para a tomada de decisões que atingem toda a coletividade. A infraestrutura social da esfera pública consiste em um leque abrangente de atores que contribuem para a formação da opinião, os quais, em seus diferentes formatos (tais como movimentos sociais, associações, sindicatos, subgrupos culturais, mídias alternativas, etc.), abarcam temas e demandas plurais. Nesses termos, ela é apresentada como uma "caixa de ressonância" para problemas que devem ser trabalhados pelo sistema político, formando um sistema de alarme com sensores não-especializados, porém sensíveis no âmbito de toda sociedade.

Por outro lado, o autor nos diz que a esfera pública somente é capaz de cumprir livremente sua função de captar e tematizar os problemas da sociedade como um todo na medida em que pode contar com fluxos comunicativos provenientes da esfera privada. Habermas descreve o fluxo comunicativo responsável pela formação política da vontade como tendo sua base na assimilação privada de problemas sociais que repercutem nas biografias particulares. Para o autor, a esfera privada se situa no interior da periferia dos processos políticos como seu ponto mais distante dos núcleos institucionalizados 
de tomada de decisão, o que lhe confere uma posição germinal nos processos sociais responsáveis pela formação legítima da vontade. Antes de serem tematizados pela esfera pública, os novos problemas sociais encontrariam suas primeiras repercussões nos sofrimentos gerados pelas experiências de insucesso verificadas nos projetos de vida individuais, entre as quais se incluem as consequências externalizadas da autoprogramação dos sistemas político e econômico. Ao estruturar formas de comunicação de acesso reservado, a esfera privada mostrar-se-ia como um dos principais veículos para um tipo de linguagem existencial segundo a qual tais experiências são espontaneamente narradas pelos próprios concernidos em contextos cotidianos de socialização.

Por dependerem fundamentalmente de contribuições privadas como a base do fluxo comunicativo que os constituem, os processos públicos de formação da vontade tanto mais poderão ser considerados autônomos quanto mais estiverem fundadas em uma esfera privada intacta, caracterizada pela liberdade de escolha e expressão entre modos de vida distintos e percepções específicas da sociedade. Inversamente, na descrição da passagem dos impulsos políticos periféricos ao centro do poder, fica claro que os fluxos comunicativos que emergem da privacidade têm de ser complementados pela esfera pública: a percepção dos novos problemas é cumprida na esfera privada de uma forma não-intencional, pouco elaborada e predominantemente personalista - sem que possamos considerá-los propriamente como temas de controvérsias públicas abrangentes. Com a iniciativa de atores que lançam tais fluxos comunicativos em fóruns públicos, eles podem ser devidamente elaborados, condensados na forma de grandes temas e posições firmadas a seu respeito, dramatizados como questões de relevância pública para, ao final, terem a chance de influenciar o sistema político e transformar a agenda oficial de problemas.

Sendo assim, o vínculo entre autonomia pública e privada não permanece aqui preso aos simples termos de suas referências conceituais recíprocas. No âmbito dessa sociologia reconstrutiva da de- mocracia, a gênese dos impulsos políticos subinstitucionais depende factualmente de fluxos comunicativos produzidos espontaneamente em esferas públicas e privadas autônomas, as quais operam de maneira complementar. Para Habermas, a transformação da agenda política, nas últimas décadas, revela não apenas que a esfera pública encontra-se muito ligada aos domínios da vida privada, mas que os fluxos comunicativos que emergem da privacidade encontram nela a possibilidade de serem contrapostos à inércia sistêmica da política institucional. Amparando-se em estudos de Joachin Hachke, Jean Cohen e Andrew Arato, Habermas defende que a reabilitação das lutas políticas subinstitucionais revela tanto o vínculo dos "novos movimentos sociais" com problemas identitários que ressoam de maneira similar nas biografias de seus membros, quanto seu comprometimento com metas políticas voltadas à reelaboração das estruturas sociais do mundo da vida.

O percurso levado a cabo em Direito e Democracia, entretanto, não termina com as análises acerca das condições de possibilidade para a inversão dos fluxos do poder oficial. Mesmo após a difícil tarefa de penetrar as clivagens institucionais por meio de processos deliberativos densos e inserir novos problemas na agenda política oficial, os fluxos comunicativos provenientes da sociedade civil ainda não podem ser considerados capazes de romper a autoprogramação das instituições decisórias. Eles se encontram ali sujeitos à força de adaptação das práticas discursivas institucionalizadas e correm o risco de ter seus novos temas e demandas inteiramente diluídos em compreensões tradicionais acerca do direito e da sociedade. Vale dizer, as contribuições introduzidas pela esfera pública chocam-se com o pano de fundo de saberes especializados pressupostos no funcionamento habitual das instituições jurídico-decisórias, os quais pré-definem a caracterização das questões sociais a elas levadas segundo formas paradigmáticas de sua interpretação.

O último capítulo da obra é dedicado à reconstrução dos "paradigmas jurídicos", isto é, das imagens sociais que orientam as práticas con- 
cretas de criação e aplicação normativa. te no percurso dos processos políticos. Deixamos Habermas parte aqui da percepção de que o dis- o campo de investigação que se dedicava estritacurso jurídico nunca opera em abstrato, isto é, que as argumentações em torno da fundamentação e interpretação de direitos sempre se baseiam, mesmo que de modo implícito, em uma determinada compreensão da realidade social. Ao mesmo tempo, representações sociais compartilhadas entre os operados do direito geram padrões de entendimento mais ou menos homogêneos acerca daquilo que é, ou deve ser, o próprio sistema jurídico. Dessa forma, Habermas nos diz que a noção de paradigma jurídico nos permite identificar os "laços de sentido" entre configurações determinadas do sistema jurídico e uma correspondente compreensão do ambiente social na qual ele se encontra inserido.

A posição dessas novas investigações no interior de Direito e Democracia não é casual, já que a atividade reconstrutiva aqui operada irá mobilizar desenvolvimentos contidos ao longo de toda a obra. Nesse sentido, Habermas escreve, já no prefácio, que "o último capítulo tenta reagrupar as considerações sobre teoria do direito e sobre teoria da sociedade servindo-se do paradigma jurídico procedimental" (Habermas, [1992, p. 10] 1997, v. I, p.10-11) e, mais adiante, no capítulo primeiro: "esta linha de uma teoria da sociedade e de uma teoria do direito, apoiadas no princípio do discurso, torna possível introduzir um paradigma procedimental do direito" (Habermas, [1992, p.22] 1997, v.1, p.24). Trata-se, pois, de um momento culminante de todo o percurso, construído a partir do cruzamento entre as reconstruções interna e externa anteriormente operadas. Por um lado, percebemos que Habermas continua aqui essencialmente ligado a uma das preocupações mais centrais de toda a reconstrução externa, a saber, investigar as condições e bloqueios para que os fluxos comunicativos da esfera pública consigam penetrar efetivamente os capilares do sistema burocrático e romper com seus modos tradicionais de elaboração de problemas. Por outro lado, entretanto, é importante perceber que demos um passo adianmente às relações externas entre Estado e sociedade, passando a habitar novamente o interior dos discursos jurídicos especializados - tendo agora por objeto não mais sua autocompreensão teórica, mas as representações sociais contidas nas práticas de criação e aplicação normativa. Essa retomada dos discursos jurídicos é necessária, já que agora apresenta um sério entrave à política deliberativa: os paradigmas jurídicos historicamente vigentes transformam esses laços de sentido em ideias fixas, em matéria transitada em julgado. Eles podem vir a tornar infrutífera a política deliberativa, já que, mesmo na hipótese de uma transposição eficiente das clivagens institucionais, os fluxos comunicativos que emergem da sociedade civil encontram, no discurso jurídico, um enquadramento dogmático pré-fabricado.

Na caracterização dos paradigmas jurídicos historicamente vigentes, Habermas apoia-se inicialmente em investigações de intelectuais como O. Kahn-Freund, F. Kübler e H. J. Steiner, os quais pretendiam desvelar o ideal social pressuposto pelo direito formal burguês nos termos de uma "crítica da ideologia". Em linhas gerais, o paradigma liberal estaria fundado na compreensão de uma sociedade econômica desacoplada do Estado e entregue à ação espontânea dos mecanismos de mercado. Tal "sociedade de direito privado", institucionalizada principalmente através de direitos de propriedade e da liberdade de contratos, seria organizada segundo a autonomia individual dos sujeitos de direito, os quais, como atores econômicos independentes, procurariam encontrar sua autorrealização no cumprimento de interesses próprios. Sua maneira própria de conceber o sistema jurídico seria dada nos estritos termos da "igualdade formal", isto é, nos termos de uma distribuição idêntica de competências jurídicas civis e políticas entre todos, independentemente de quaisquer tipos de determinantes sociais. Assim, o modelo sustentava-se em pressuposições sociais ligadas à existência de condições não-discriminatórias para o 
aproveitamento das mesmas liberdades entre todos, fundamentalmente, o equilíbrio dos processos econômicos organizados pelo o mercado, a distribuição aproximadamente igual do poder social e o exercício em igualdade de chances das competências definidas pelo direito privado. Tais pressupostos fáticos puderam ser um a um questionados, e sua refutação empírica revelou a incapacidade de o modelo liberal cumprir as pretensões normativas por ele próprio sustentadas. Suas insuficiências descritivas, ligadas à cegueira quanto às desigualdades de poder econômico e de posições sociais, acabavam por encobrir e reforçar chances desiguais de autorrealização e limitar a liberdade individual que pretendia promover.

O novo contexto do direito materializado vem acompanhado de uma nova compreensão da sociedade e da relação entre Estado e indivíduo: surge a imagem de uma sociedade cada vez mais complexa, na qual a economia figura como uma esfera de ação funcional que expõe o ator individual a fragilidades de uma distribuição de renda potencialmente injusta, limitando as possibilidades de ação segundo sua específica lógica instrumental. À fragilidade do indivíduo frente às assimetrias do poder econômico é ligada a expectativa normativa de que as contingências do mercado sejam controladas através das operações reguladoras de um Estado social que intervém de modo reativo e que complementa as liberdades formais com provisões positivas no acesso à saúde, educação, habitação e ao trabalho. O sujeito de direito, que, segundo a compreensão liberal, detinha toda a liberdade necessária à persecução de seus interesses individuais, passa a figurar como "cliente" de uma burocracia planejadora, tornando-se grande parte de suas liberdades de ação dependentes das atividades da administração estatal.

Esse novo paradigma mostrou-se mais uma vez vulnerável a críticas: sua compreensão da sociedade teria se revelado excessivamente pautada nos modos de reprodução do capitalismo industrial, sendo acusado tanto de naturalizar grupos e necessidades particulares em função de suas posições no sistema produtivo, quanto de ignorar toda ordem de desigualdades alheias aos termos "da posse e da aquisição". No que se refere a seu modelo jurídico, o paradigma do Estado social teria mostrado dificuldades em adequar suas intervenções redistributivas à própria preservação da liberdade. Habermas salienta que o Estado providente correria o risco de prejudicar, através de suas intervenções antecipadas, a própria autonomia que, em princípio, deveria proteger. Isso porque a expansão do campo regulatório não viria acompanhada de uma ampliação correspondente dos debates público-políticos a seu respeito. Ao contrário, a regulação social seria marcada por um processo de profunda burocratização, caracterizado pela substituição dos debates normativos por questões técnico-administrativas e pelo afastamento dos próprios destinatários dos processos responsáveis por sua elaboração. E, para se fazerem contemplados, os cidadãos seriam obrigados a adaptar suas condutas a padrões de comportamento fixados heteronomamente nos critérios de incidência de programas sociais.

Para Habermas, apesar das longas disputas que envolvem historicamente esses dois paradigmas, ambos apresentariam características bastante similares. Com efeito, o enquadramento dos casos particulares é cumprido por ambos mediante macrovisões substantivas da sociedade, as quais limitam ou mesmo impedem a incorporação de novas compreensões e problemas sociais. Dessas macrovisões, por sua vez, são derivados diretamente programas jurídicos fixos, sendo eles próprios apenas parcialmente distintos: o paradigma do Estado social vem apenas somar uma categoria nova de direitos sociais como medida necessária à correção das assimetrias econômicas, sem alterar significativamente a própria estrutura das liberdades civis e políticas, as quais continuam sendo habitualmente distribuídas segundo os termos da igualdade formal. Por fim, ambos os paradigmas visam à promoção direta da autonomia privada, sem fomentar a autonomia pública dos cidadãos 
como sua condição mesma de possibilidade. Nesse sentido, eles promovem práticas jurídicas profundamente marcadas pelo "privatismo" e centralismo estatal.

Habermas encontra, na dogmática jurídica contemporânea, tentativas de superar o paternalismo do Estado social por meio de projetos regulatórios que fizessem jus a uma compreensão procedimentalista do direito. Tais tentativas procurariam, em sua maior parte, reduzir as competências de criação e aplicação de normas substantivas das instâncias estatais de tomada de decisão, acomodando-se a uma ideia de "direito reflexivo" que pudesse ampliar as possibilidades de decisão e autogestão dos próprios sujeitos de direito - seja pela via da expansão das ações processuais, seja pela delegação de competências diretas para a "autogeração de normas". Para o autor, entretanto, é em certos desenvolvimentos do feminismo contemporâneo que encontramos as intuições melhor acabadas desse novo paradigma. Ele submete as fronteiras tradicionais entre público e privado a uma disputa política constante, a qual parte de críticas e reelaborações reflexivas da autocompreensão cultural da sociedade e as confronta com as formas vigentes de sua institucionalização jurídica, entre as quais se encontram cristalizadas distinções rígidas acerca da divisão sexual do trabalho, da identidade de gêneros e de seus espaços típicos de ação. Denunciando os efeitos colaterais de programas jurídicos tutelares, os quais reforçariam os "papéis tradicionais entre gêneros" e "os estereótipos depreciativos da mulher", o feminismo teria encampado uma luta pela constituição pública das próprias categorias identitárias com as quais pretendem ser representadas juridicamente e pelo enquadramento jurídico adequado de demandas sociais articuladas originalmente na linguagem de não-especialistas.

Para Habermas, esses casos nos revelam esforços em andamento contra a petrificação de ambos os termos que constituem um paradigma jurídico, vale dizer, tentativas de procedimentalizar tanto a compreensão dos aspectos da vida social merecedores de tratamento jurídico, quanto a disputa pelas formas regulatórias mais adequadas a cada caso. A noção de paradigma procedimental procura exprimir o caráter continuado e inconclusivo desses esforços democratizantes. De um lado, pois, ele não determina um novo modelo substantivo de sociedade que substituísse aqueles presentes nos paradigmas anteriores, mas exige que as instituições jurídicas se mantenham reflexivamente abertas às novas percepções da realidade social geradas nos processos deliberativos de formação da consciência e da vontade. De outro lado, não temos aqui a fixação prévia de um modelo jurídico a ser aplicado às novas demandas sociais. O paradigma procedimental não elimina as estratégias regulatórias mais características dos paradigmas anteriores, mas tão somente seu caráter de necessidade dogmática. Vale dizer, ele "não privilegia uma forma de direito específica [...], da mesma maneira como o paradigma liberal e do Estado social privilegiavam, respectivamente, o direito formal e material". Seu distanciamento em relação à dogmática dos paradigmas anteriores situase no desbloqueio das possibilidades de normatização jurídica e em sua submissão a processos decisórios públicos e argumentativamente motivados. Tais exigências democratizantes, entretanto, não se cumprem enquanto o discurso jurídico permanecer preso ao círculo hermético de seus operadores. Habermas caracteriza a regulamentação jurídico-democrática como um processo que exige o esclarecimento público acerca dos aspectos relevantes para uma posição de igualdade entre todos, o qual não pode ser substituído pelo saber técnico dos especialistas em direito:

O paradigma jurídico procedimental procura proteger, sobretudo, as condições do procedimento democrático. Elas adquirem um estatuto que permite analisar, sob outra luz, os diferentes tipos de conflito. Os lugares antes ocupados pelo participante privado do mercado e pelo cliente das burocracias do Estado de bem-estar social são assumidos por cidadãos que participam de discursos públicos, articulando e fazendo valer interesses feridos, e colaboram na formação de critérios para o tratamento igualitário de casos iguais e 
para o tratamento diferenciado de casos diferentes. [...] O fardo dessa legitimação suplementar poderia ser assumido pela obrigação de apresentar justificações perante um fórum jurídico crítico. Isso seria possível através da instauração de uma esfera pública jurídica capaz de superar a atual cultura de especialistas e suficientemente sensível para transformar as decisões problemáticas em foco de controvérsias públicas. (Habermas, [1992, p.529-530 ] 1997, v.2, p.183).

\section{PERPECTIVAS E LIMITAÇÕES}

Para Habermas, uma compreensão crítica do Estado democrático de direito não se faz meramente com a denúncia de seus inúmeros insucessos. Trata-se de pensá-los como bloqueios a suas potencialidades mais amplas. Nesse sentido, ela procura reconstruir as condições procedimentais ante as quais pode se mover um processo de democratização radical. Esse empreendimento crítico, como vimos, não se mostra uma tarefa fácil: ele exige a desnaturalização de todos os conteúdos que historicamente ergueram o edifício jurídico-democrático sem, entretanto, privá-lo de certas estruturas conceituais e orientações normativas básicas que o permitam permanecer de pé. A atividade crítica, entretanto, não deve se encerrar por aí. Como o percurso que acompanhamos deixa claro, a teoria crítica de Habermas não pretende substituir os processos democráticos. Pelo contrário, ao reconstruir os diferentes elementos do Estado democrático de direito segundo um modelo procedimental, todo conteúdo "suspenso" pela teoria passa a ser objeto da práxis democrática de formação política da vontade. E em virtude disso, não se exime a atividade crítica de constantes avaliações e posicionamentos ante questões políticas substantivas. Tais posicionamentos, inclusive, podem gerar a necessidade de a teoria reformular suas reconstruções acerca das possibilidades e bloqueios da práxis político-democrática. Para o autor, contudo, os posicionamentos políticos substantivos não devem procurar ocupar o lugar da teoria democrática, sob pena de nela produzi- rem formas de engessamento contrárias a seu próprio objeto.

Ao lado dessa autolimitação da teoria crítica operada por Habermas, podemos indicar aqui outra gama de limitações não-intencionais; vale dizer, limitações relativas ao cumprimento de seu projeto crítico tal como proposto em Direito e Democracia. Se tal projeto encontra-se vinculado à "desnaturalização" e à consequente "politização" das categorias estruturadoras do direito moderno, acompanhadas de análises sobre as condições de possibilidade gerais para que esse movimento se reproduza em processos políticos reais, ele se mostra ainda marcado, em cada um de seus passos reconstrutivos, por resquícios naturalizantes que merecem ser combatidos. No âmbito da reconstrução interna, por exemplo, Habermas nomeia o elemento coercitivo como característica imanente e necessária da forma jurídica, a qual se completa nas formas institucionalizadas de sanção estatal ao descumprimento de normas formais. Esse apego excessivo à sansão punitiva não acompanha de perto tentativas de desnaturalização do vínculo entre pena e imputação jurídica desenvolvidas no interior do próprio campo crítico. Habermas assume, no prefácio do livro, que suas análises se furtam à reconstrução do direito penal, atribuindo essa tarefa a trabalhos de Klaus Günther em andamento. Ao entrarmos em contato com os resultados desses trabalhos, entretanto, salta-nos justamente aos olhos o empenho de Günther em transformar a sanção punitiva em um elemento contingente, não-necessário, da regulação jurídica:

As razões e justificativas apresentadas no discurso oficial e público sobre a pena não resistem, portanto, a um exame mais detalhado. As alegadas relações de meio e fim entre a pena e seus efeitos não são acertadas ou são impossíveis de se comprovar. [...] Como nas variantes mais modernas da teoria da retribuição, nas teorias da prevenção geral e positiva a pena, entendida como a inflição de um mal ordenado e executado pelo Estado, é também reduzida a um meio de comunicação. Por que tais mensagens precisam ser comunicadas justamente por meio da pena permanece uma questão em aberto. Seu conteúdo proposicional poderia ser comunica- 
do também por intermédio de outros atos performativos, como uma condenação em um processo público e formalizado de determinação dos fatos e da imputação. O nexo entre a mensagem mediada pela comunicação e o meio de comunicação da pena continua sendo contingente; não está comprovada a existência de uma relação necessária. (2009, p.72-73)

Günther certamente não tem a intenção de suprimir por completo a pena da autocompreensão dogmática do direito, mas tão somente seu caráter de necessidade: "A crítica da pena deve desembocar em uma crítica da necessidade de punição" (2009, p.87). Habermas não acompanha esse movimento; vale dizer, pressupõe a sanção punitiva sem reconstruí-la devidamente. E essa negligência com respeito a um dos elementos mais centrais da facticidade jurídica impõe-lhe o risco de ver suas intenções democratizantes radicais desaguarem em uma compreensão tradicional do processo democrático. Em uma teoria procedimental do direito e da democracia, não apenas o sentido da pena (retributivo, preventivo, reintegrador, etc.) como sua própria vinculação a comportamentos determinados devem ser apresentados como possibilidades regulatórias a serem escolhidas pelos cidadãos por meio de sua autonomia pública. Nas palavras de Klaus Günther, a pena deve ser apresentada como "um meio entre outros para o reconhecimento da norma”. Não se trata aqui, portanto, de cobrar uma justificação normativa da forma coercitiva, mas, ao contrário, de submeter sua justificação mesma ao campo políticodemocrático (2009, p.72).

No âmbito da reconstrução externa, são diversas as acusações de "déficits sociológicos" direcionados à obra de Habermas. Desde Kritik der Macht, de Axel Honeth, são comuns as críticas que apontam a negligência de Habermas com relação a patologias sociais e formas ilegítimas de poder que se impõem sem fazer uso da mediação sistêmica, tais como a distribuição desigual do capital simbólico, o controle da mídia sobre a formação das agendas públicas informais e formas de dominação cultural independentes das estruturas burocráticas (Honneth, 1988; Young, 2001; Benhabib, 2002). Entre os potenciais nãodiagnosticados, podemos mencionar sua insensibilidade em relação às possibilidades de participação política direta e às formas de influência do sistema político não-mediadas pelas instituições parlamentares. Uma crescente bibliografia chama a atenção para as chances de modificação dos fluxos do poder burocrático por meio de demandas que alcançam instituições não-legislativas, tais como conselhos participativos, órgãos de accountability vertical e as próprias instituições judiciárias (Epp, 1998; Fanti, 2009; Wilson; Cordero, 2006; Glopen, 2008). Argumenta-se, inclusive, que grupos pouco organizados, socialmente marginalizados e com baixa representatividade na política oficial, podem encontrar no judiciário maiores chances de alterar políticas públicas e reinterpretar o alcance de seus direitos (Wilson; Cordero, 2006, p.331-332). Tais análises destoam do diagnóstico habermasiano sobre a política deliberativa, no qual as instituições legislativas parecem cumprir o papel de lugar natural para onde escoam todas as demandas sociais que emergem no mundo da vida.

Ao lermos de forma panorâmica os desenvolvimentos do último capítulo de Direito e Democracia, encontramos a tese de que uma compreensão mais completa e aprofundada da práxis jurídica contemporânea exige o cruzamento da perspectiva jurídica com a sociológica. As consequências dessa tese mais geral, entretanto, não são todas trabalhadas nos próprios limites da obra. Vale dizer, a intersecção desses dois campos disciplinares abre possibilidades de análise não inteiramente esgotadas pelo autor. A noção de paradigma jurídico apresenta-nos, sem dúvida, um exemplo profícuo sobre os modos como essa intersecção pode se dar, mas encontra-se longe de ser o único. Ao invés de nos deter na imagem social utilizada na fundamentação e aplicação do direito, cabe perguntar pelas estruturas sociais legitimadas nos termos do direito, pelo acesso diferenciado de seus autores-destinatários, pelo modelo regulatório privilegiado em 
diferentes esferas sociais, pelo caráter das demandas mais habitualmente vetadas pelas instituições decisórias, pela composição efetiva dos processos responsáveis por decisões emblemáticas, etc. Essas perguntas, que não são novas nas vertentes críticas do pensamento sobre o direito, não encontram inscrição adequada na sociologia jurídica modesta operada em Direito e Democracia.

Seja em virtude de seus limites assumidos, seja em razão das limitações atribuídas, a crítica do direito e da democracia em Habermas se conclui como um projeto inacabado. E é importante que ela seja assim compreendida. A obra de Habermas é mais rica quando entendida não como um sistema filosófico fechado, mas como um programa de pesquisa. Ela abre perspectivas para uma compreensão mais ampla dos processos democráticos reais, a qual não se prende às instituições da política oficial, muito embora crie ferramentas teóricas aptas a descrevê-las e avaliá-las. De um ponto de vista crítico, o caráter inconclusivo de sua obra deixa claro que os princípios normativos do direito moderno não se realizaram plenamente. A forma abstrata de apresentação de suas categorias fundamentais reflete a insuficiência de qualquer um de seus conteúdos historicamente determinados - cabendo insistir, uma vez mais, que essa forma de apresentação não decide ela mesma questões práticas em abstrato. Ao contrário, em cada “dessubstancialização" e "procedimentalização" empreendida, procura-se ampliar os horizontes da práxis política cotidiana. Ao terminar com processos de realização de direitos em andamento, o autor reafirma seu modelo inicial de emancipação: trata-se de um modelo procedimental, programático, inconclusivo, o qual tem de se renovar em cada momento presente. Contrário às cristalizações passadas, o modelo pode sugerir um caráter puramente iconoclasta. Tal leitura, entretanto, é parcial. O modelo, de fato, combate os pressupostos do direito e da democracia enquanto pressupostos, mas procura reconstruílos em suas possibilidades mais alargadas.
(Recebido para publicação em 28 de junho de 2011)

(Aceito em 19 de julho de 2011)

\section{REFERÊNCIAS}

BENHABIB, S. Critique, norm and utopia. A study of the foundations of critical theory. New York: Columbia University Press, 1986.

The claims of culture. Equality and diversity in the global era. Princeton: Princeton University Press, 2002. COHEN, J. Class and civil society. The limits of marxian critical theory. Amherst: The University of Massachusetts Press, 1982.

EPP, C. The rights revolution: lawyers, activists and Supreme Courts in comparative perspective. Chicago: Chicago University Press, 1998.

FANTI, F. Políticas de saúde em juízo: um estudo sobre o Município de São Paulo. 2009. Dissertação (Mestrado) Faculdade de Filosofia e Ciências Humanas da Universidade de São Paulo. 2009.

GLOPPEN, S. Public interest litigation, social rights and social policy. In: DANI, A. A.; HAAN, A. (Ed.) Inclusive states: social policy and structural inequalities. Washington: The World Bank, 2008.

GÜNTHER, K. Crítica da Pena I. In: PÜSCHEL, F. P. MACHADO, M. M. Teoria da responsabilidade no Estado democrático de direito. Textos de Klaus Günter. São Paulo: Saraiva, 2009

HABERMAS, J. Theorie des kommunikativen Handelns. Frankfurt; Main: Suhrkamp, 1987

Para a reconstrução do materialismo histórico. Trad. Carlos Nelson Coutinho. São Paulo: Editora Brasiliense, 1990.

Que significa socialismo hoje? Revolução recuperadora e necessidade de revisão da esquerda. Novo Estudos, São Paulo, CEBRAP, n.30, jul., 1991.

HABERMAS, J. Faktizität und Geltung Beiträge zur diskurstheorie des rechts und des demokratischen Rechtsstaats. Frankfurt am Main: Surkamp, $1992=($ Direito e democracia: entre facticidade e validade. Trad. Flávio Beno Siebeneichler. Rio de Janeiro: Tempo Brasileiro, 1997).

Reply to symposium participants, Benjamin N Cardozo School of Law. In: ROSENFELD, M., ARATO, A. (Ed.). Habermas on law and democracy: critical exchanges. Berkley: University of California Press, 1998

HONETH, A. Kritik der macht. Reflexionstufen einer kritischen Gesellschaftstherorie. Frankfurt; Main: Suhrkamp, 1988.

Social dinamics of disrespect: situating Critical Theory today. In: DEWS, P. (Ed.). Habermas: a critical reader. Oxford: Blackwell, 1999

HORKHEIMER, M. Teoria tradicional e teoria crítica. São Paulo: Abril Cultural, 1975. v.98 (Coleção os pensadores)

NOBRE, M. A ideia de teoria crítica. In: MÜLLER, M. C. CENCI, E. M. (Org.) Ética, política e linguagem. Confluências. Londrina: Edições CEFIL, 2004.

A teoria crítica. Rio de Janeiro: Jorge Zahar Ed.

PETERS, B. Die integration moderner Geselschaften. Frankfurt; Main: Suhrkamp, 1993. 
REPA, L. S., A transformaçao da filosofia em Jürgen YOUNG, I. M. Justice and the politics of difference. Habermas: os papéis da reconstruçao, interpretaçao e críti- Princeton: Princeton University Press, 1990.

ca. 2004. Tese (Doutorado) - Faculdade de Filosofia e Ciências Humanas da USP. São Paulo: 2004.

Inclusion and democracy. Oxford: Oxford

SILVA, F. G. Solidariedade entre publico e privado. In: NOBRE, M.; TERRA, R. (Org.) Direito e democracia - um guia de leitura. São Paulo: Malheiros, 2008.

WILSON, B. M.; CORDERO, J. C. R. Legal opportunity structures and social movements: the effects of institucional change on Costa Rican politics. Comparative Political Studies, London, SAGE, v.39, n.3, 2006. 


\section{BETWEEN POTENTIALS AND COMMUNICATION \\ BLOCKS: Habermas and the critique of the democratic rule of law}

\author{
Felipe Gonçalves Silva
}

For Habermas, a critical understanding of the democratic rule of law is not made merely with the denunciation of its many failures. It is about investigating them as blocks to its true potentialities. Thus, in Law and Democracy, the author tries to reconstruct the procedural conditions against which a process of radical democratization can move, putting the key elements of the democratic rule of law to a discursive model of critical theory, which turns to the use of a comunicative potentialities released in modernity. Starting from the lins of Law And Democracy to the critical theory of society, this paper aims to clarify the particular traits of the critical model there developed, as well as highlight some of its characteristic limitations.

KEYwords: Habermas, democracy, rule of law, critical theory, proceduralism.

\section{ENTRE POTENTIELS ET BLOCAGES COMMUNICATIFS: Habermas et la critique de l'État de droit démocratique}

Felipe Gonçalves Silva

Pour Habermas, une compréhension critique de l'État de droit démocratique ne se fait pas simplement en dénonçant ses nombreux échecs. Il faut les examiner en tant que blocages de leurs véritables potentiels. Ainsi, dans Droit et Démocratie, l'auteur essaie de reconstruire les conditions de procédures permettant à un processus démocratique radical de se déclencher en soumettant les éléments fondamentaux de l'État de droit démocratique à un modèle discursif de la théorie critique, dont la tendance est de profiter des potentiels communicatifs libérés dans la modernité. En partant des liens que Droit et Démocratie a avec la théorie critique de la société, l'article vise à expliquer les traits particuliers du modèle critique qui y est développé ainsi qu'à souligner quelques-unes de ses limites caractéristiques.

Mots-CLÉs: Habermas, démocratie, État de Droit, théorie critique, procéduralisme.

Felipe Gonçalves Silva - Doutor em Filosofia pela Universidade Estadual de Campinas. Integra o Núcleo de Pesquisa Direito e Democracia do Centro Brasileiro de Análise e Planejamento (CEBRAP), desenvolvendo pesquisas nas áreas de Teoria Crítica, Esfera Pública e Pensamento Democrático. 